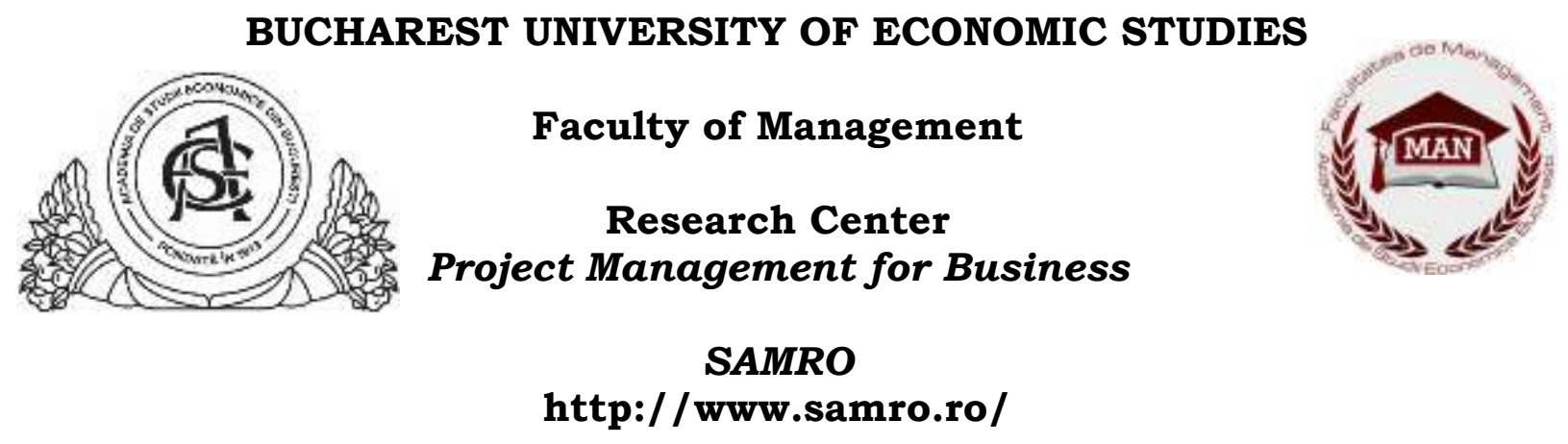

\title{
Management and Economics Review
}

\author{
Vol. 5, Issue 1/2020 (June)
}

ISSN 2501-885X

www.mer.ase.ro

email: mer@man.ase.ro

Bucharest

Editura ASE 


\section{Editorial board:}

Editor-in-chief: Carmen Nadia Ciocoiu Managing editor: Corina Marinescu Co-editors: Sofia Elena Colesca, Claudiu Cicea

\section{Scientific board:}

Adrian Curaj, Politehnica University of Bucharest, Romania

Aleksy Kwilinski, The London Academy of Science and Business, United Kingdom

Aniko Csepregi, University of Pannonia, Hungary

Anne Charllote Taillandier, Universite d'Artois, France

Antonio Natera Peral, Universidad Carlos III de Madrid, Spain

Baiba Savrina, University of Latvia, Latvia

Basarab Gogoneata, Bucharest University of Economic Studies, Romania

Catalina Crisan, Babes-Bolyai University, Romania

Catalina Radu, Bucharest University of Economic Studies, Romania

Constantin Bratianu, Bucharest University of Economic Studies, Romania

Cosmin Dobrin, Bucharest University of Economic Studies, Romania

Cristian Tiu, University at Buffalo, USA

Daniela Grigori, Universite Paris-Dauphine Paris 9, France

Francisco Puig, Universidad de Valencia, Spain

Ion Partachi, University of Economic Studies from Moldova, Moldova

Ion Popa, Bucharest University of Economic Studies, Romania

Irina-Eugenia Iamandi, Bucharest University of Economic Studies, Romania

Irina Salanta, Babes-Bolyai University, Romania

Joanna Sadkowska, University of Gdansk, Poland

Jonel Subic, Institute of Agricultural Economics, Belgrad, Serbia

Krystyna Leszczewska - Lomza State University of Applied Sciences (PWSIP), Poland

Lefteris Tsoulfidis, University of Macedonia, Thessaloniki, Greece

Maria da Conceição Pereira Ramos, Universidade do Porto, Portugal

Miguel Gonzalez-Loureiro, University of Vigo, Spain and Polytechnic of Porto, Portugal

Minodora Ursacescu, Bucharest University of Economic Studies, Romania

Monica Dudian, The Bucharest University of Economic Studies, Romania

Philipe Duez, Universite d'Artois, France

Răzvan Andrei Corboș, Bucharest University of Economic Studies, Romania

Răzvan Cătălin Dobrea, Bucharest University of Economic Studies, Romania

Roberto M. Constantino T., Metropolitan Autonomous University - X, Mexico

Salmi Mohd Isa, Graduate School of Business, Universiti Sains Malaysia, Malaysia

Sebastian Mădălin Munteanu, Bucharest University of Economic Studies, Romania

Simona Ștefan, Bucharest University of Economic Studies, Romania

Stephane Callens, Universite d'Artois, France

Vandana Deswal, Sheridan College, Toronto, Canada

\section{ISSN 2501-885X}

\section{Published by: Editura ASE}

Piata Romana no. 6, sector 1, code 010374 , Bucharest, Romania

Telephone numbers: +4(021) 319.19.00 /

ext. 146, 460

www.editura.ase.ro, editura@ase.ro

Editorial director: Simona Buşoi

Editor: Silvia Răcaru

Typesetter: Silvia Despa

Cover design: Livia Radu

The responsibility for opinions expressed by articles belongs to authors. 


\section{Table of contents}

Risk Management Practices in Small and Medium Enterprises:

Evidence from Romania 1

Adina-Liliana PRIOTEASA

Nicoleta CHICU

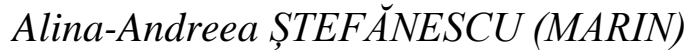

Alexandru Mihai BUGHEANU

Ruxandra DINULESCU

Customer Retention of Mobile Phone Purchasing on Cell Phone Stores in Denpasar 16

Anak Agung Ngurah Gede SADIARTHA

Clustering Consumers through their Consumption Behavior:

Analysis on the Fashion Industry.

Andreea-Ionela PUIU

Online Purchasing and its Determinants: An Experimental Approach

Zafer AKIN

Analysis of the Influence of the Emotional, Intellectual and Spiritual Intelligence on Employee Performance with Work Motivation as a Moderating Variable

Cheng-Wen LEE

Alum KUSUMAH

Is Emotional Intelligence a Determinant Factor for Leader's Skills Development?

Essential Literature Perspectives

Ştefan Gabriel BURCEA

Oana Matilda SABIE

Improving the Engineering Students' Entrepreneurial Self-Efficacy

through a Specialised Course - A Way to Improve Startup Management .78

Andrei DUMITRESCU

Volunteering in the Heritage Sector: Opportunities and Trends

Mihaela P $\breve{A C E S S I L ~} \breve{A}$

Overview and Analysis of Industry in Vietnam under Taiwan's Southbound Policy

Tzu-Yi YANG

Nguyen Phuc NGUYEN

Wen-Chuan FU

Chia-Jui PENG

Employment Absorption: Elasticity in the Industry and Services Sector in Indonesia ....125

Dio Caisar DARMA

Jati KASUMA

Muhammad IKBAL 
Female Labor Force Participation Rate in Indonesia: An Empirical Evidence from Panel Data Approach. 136

Gatot SASONGKO

Bernard Edheney HURUTA

Andrian Dolfriandra HURUTA

Sustainable Growth Rate: Between Fixed Asset Growth and Firm Value

Nur LISTIANI

Supramono SUPRAMONO

The Challenges Facing Expatriate Managers Working in Foreign Countries 160

Murad Muzafer HAMZE

Managing the Transformation of Traditional to Organic Agriculture in Pune District: A Long Term Policy Framework.

Sanjay RODE 